\title{
ONE-STEP PURIFICATION OF TWO SEMI-SYNTHETIC EPICATECHIN ADDUCTS PREPARED FROM AVOCADO PEELS PROCYANIDINS BY CENTRIFUGAL PARTITION CHROMATOGRAPHY AND EVALUATION OF THEIR ANTI-INFLAMMATORY EFFECTS ON ADENOCARCINOMA GASTRIC CELLS INFECTED WITH Helicobacter pylori
}

\author{
EILLEN TORRES ${ }^{1,6}$, APOLINARIA GARCÍA ${ }^{1}$, MARIO ARANDA ${ }^{2}$, VANIA SAÉZ $^{3}$, FELIPE ZÚNIIGA ${ }^{4}$, \\ JULIO ALARCÓN 5 , MARCIA AVELLO ${ }^{6}$ AND EDGAR PASTENE ${ }^{6 *}$ \\ ${ }^{1}$ Laboratory of Bacterial Pathogenicity, Department of Microbiology, Faculty of Biological Sciences, University of Concepcion, Concepcion, Chile. \\ ${ }^{2}$ Laboratory of Mass Spectrometry, Department of Science and Food Technology, Faculty of Pharmacy, University of Concepcion, Concepcion, Chile. \\ ${ }^{3}$ Department of Instrumental Analysis, Faculty of Pharmacy, University of Concepcion, Concepcion, Chile \\ ${ }^{4}$ Department of Clinical Chemistry and Immunology, Faculty of Pharmacy, University of Concepcion, Concepcion, Chile. \\ ${ }^{5}$ Laboratory of Synthesis and Natural Products, Department of Basic Sciences, Faculty of Sciences, University of Bio-Bio, Chillán, Chile. \\ ${ }^{6}$ Laboratory of Pharmacognosy, Department of Pharmacy, Faculty of Pharmacy, University of Concepcion, Concepcion, Chile. \\ * Correspondence to: Edgar Pastene, Laboratory of Pharmacognosy, Department of Pharmacy, Faculty of Pharmacy, University of Concepcion, \\ Barrio Universitario S/N, PO Box 237, Concepción, Chile.
}

\begin{abstract}
Avocado peels were used to extract proanthocyanidins (PACs) as starting material to prepare semi-synthetic derivatives of epicatechin by nucleophilic attack with pyrogallol and resorcinol. One-step isolation of both semi-synthetic derivatives was successfully performed through centrifugal partition chromatography (CPC), and identified by TLC and LC-MS/MS. The effect upon adherence of Helicobacter pylori ATCC 43504 to AGS cells and the subsequent induction of proinflammatory IL-8 release was tested for these two semi-synthetic derivatives. Bacterial adherence and IL- 8 synthesis was evaluated using AGS cells con-infected with FITC-labeled H. pylori. Concentration of $700 \mu \mathrm{g} / \mathrm{mL}$ of epicatechin-pyrogallol and epicatechin-resorcinol decreased $H$. pylori adherence to AGS cells to less than $20 \%$ and reduced IL-8 production to less than $10 \%$. In conclusion, semi-synthetic adducts prepared from avocado PACs reduce significantly the adherence and IL-8 production in H. pylori-infected AGS cells.
\end{abstract}

Keywords: Centrifugal Partition Chromatography, Helicobacter pylori, avocado, proanthocyanidins, IL-8.

\section{INTRODUCTION}

Proanthocyanidins (PACs) are oligomeric forms (DPm 2 to $>10$ ) of flavan3 -ols like epicathechin or catechin as main monomers [1]. In previous works, our group found that PACs extracted from apple peels can inhibit Jack bean and Helicobacter pylori ureases, which makes them an interesting natural and low toxicity supplement to prevent infections [2]. A structure-activity study established that the inhibitory effect of these compounds depends largely on its molecular size and type of monomer. In particular, it was established that the minimal active structure corresponds to dimers of PAC, being catechin-derived PACs more effective than their epicatechin-derived counterparts [3]. One of the fruits that concentrate great amounts of PAC in its peel are avocados. Given the great diversity and volumes that are exported, Chile has become the main avocado exporter in the southern hemisphere and the second largest producer and exporter in the world. Part of the volume of this fruit is destined to the elaboration of puree. In such process, large amounts of peels and seeds are generated as by-products. Polymeric PAC extracted from these by-products not only could be used as a source of $H$. pylori urease inhibitors but also as starting material for the semi-synthesis of new compounds. For instance, various low-molecular derivatives from PACs can be easily synthesized via nucleophilic attack with phenols such as phloroglucinol, resorcinol, pyrogallol or thiols like cysteine, cysteamine and toluene- $\alpha$-thiol. These latter compounds have been investigated previously because its anti-inflammatory, antioxidant and anticancer activities [4-7]. However, the biological activity of the phenolic adducts derivatives has been scarcely investigated. Helicobacter pylori $(H$ pylori) is a microaerophilic Gram-negative bacterium with great ability to colonize human gastric mucosa [8]. It has $50 \%$ prevalence worldwide and $73 \%$ in Chile [9-11]. Infection is related with gastric pathologies like gastritis, MALT lymphoma and peptic ulcer $[9,12,13]$. Importantly, due to its clear relation with gastric cancer, in the year 1994 the IARC defined $H$. pylori as a Group I human carcinogen $[14,15]$. The pharmacological regime for eradication currently combines two antibiotics (clarithromycin plus amoxicillin or metronidazole) and a proton pump inhibitor (PPI) such as omeprazole. Recent data show a decline of eradication with standard triple therapy reaching only $60 \%$ of success. Authors conclude that these results could be explained mainly due to the increasing resistance to antibiotics of $H$. pylori, especially to clarithromycin $[10,16,17]$. Because the above mentioned in the text, it is necessary to address new strategies for inhibiting the growth of this bacterium in the stomach either by reducing the inflammatory damage to the gastric mucosa, by attacking its main virulence factors or by preventing its adhesion to gastric mucosa. Therefore, the aim of the present study was to evaluate the effect of natural proanthocyanidins (PACs) compared with selected phenolic semi-synthetic derivatives against $H$. pylori. In the present work, we report for the first time the potent in vitro protective effects upon the production of proinflammatory signals (IL-8) in H. pylori-infected AGS cells.

\section{EXPERIMENTAL}

\subsection{Preparation of Avocado Peel Extract}

Avocado peels were obtained from fresh avocado fruits (Persea americana Mill. var Hass) purchased in local market. Portions of $25 \mathrm{~g}$ of peels were immediately poured into $500 \mathrm{~mL}$ of water at $80^{\circ} \mathrm{C}$ during 30 min with continuous agitation. After incubation, sample homogenization was performed using a blender (20.000 rpm) during $1 \mathrm{~min}$. This procedure was repeated until $1000 \mathrm{~g}$ of peels were extracted. Aqueous extracts were filtered though cotton and then adsorbed into columns $(40 \times 3 \mathrm{~cm})$ filled with the macroporous resin Sepabeads SP-850 pre-conditioned with water. After loading the sample, the column was washed with water ( 3 bed volumes) and the adsorbed compounds were recovered with $95 \%$ ethanol. The alcohol extracts were concentrated under vacuum and finally freeze-dried and stored at $-20^{\circ} \mathrm{C}$ until use for $\mathrm{CPC}$ fractionation.

\subsection{Preparation of semi-synthetic derivatives}

The procedure for preparation PAC-adducts was adapted from the previous work of Köhler and colleagues [18]. In brief, $1 \mathrm{~g}$ of polymeric PAC fraction, $4 \mathrm{~g}$ of nucleophile (resorcinol or pyrogallol), $3.2 \mathrm{~g}$ ascorbic acid, $5.6 \mathrm{~mL}$ concentrated $\mathrm{HCL}$ and $200 \mathrm{~mL}$ methanol were mixed. The reaction was incubated in a stirring water bath at $35^{\circ} \mathrm{C}$ for $20 \mathrm{~min}$. Then the reaction was stopped by adding $400 \mathrm{mM}$ sodium acetate [19]. The organic solvent was evaporated and the residual aqueous solution was then adsorbed into a short column $(20 \times 2.5 \mathrm{~cm})$ filled with the macroporous resin Amberlite XAD-7 HP pre-conditioned with water. After loading the reaction mix, the column was washed with water ( 3 bed volumes) to remove excess of ascorbic acid and salts. Adsorbed adducts were recovered with $80 \%$ acetone, concentrated under 
vacuum $\left(<40^{\circ} \mathrm{C}\right)$ and finally freeze-dried.

\subsection{CPC apparatus and separation procedures}

Two CPC instruments were used. For the isolation of polymeric fraction of avocado peels, a Spot-CPC 250-L centrifugal partition chromatograph (Armen, France) with a $250 \mathrm{~mL}$ total cell volume was used (CPC1). For purification of flavan-3-ols adducts a Spot-CPC-250-B Bio-Extractor was used (CPC2). Both systems have four-way switching valves that allows operation in either the descending or ascending modes. The CPC systems were connected to a SPOT.PREP II system (Armen, France), with integrated UV detector and fraction collector. CPC separation was performed with a two-phase solvent system composed of hexane-ethyl acetate-methanol-water with a volume ratio 1:9:1:9 v/v (Arizona C system) used previously in a High-Speed CounterCurrent Chromatography apparatus (HSCCC) [18]. The solvent mixture was automatically generated by the SPOT-PREP-II unit. The CPC rotor was first filled with 1.5 column volumes using the lower phase at $30 \mathrm{~mL} / \mathrm{min}$ and 500 rpm rotation. Upper phase was pumped into the system in the ascending mode at a flow rates of $6 \mathrm{~mL} / \mathrm{min}(\mathrm{CPC} 1)$ or $15 \mathrm{~mL} / \mathrm{min}(\mathrm{CPC} 2)$ and rotation was increased from 0 to $1800 \mathrm{rpm}$ and $2000 \mathrm{rpm}$ for PAC and adducts purification, respectively. After equilibrium was reached, the samples $(2 \mathrm{~g}$ of PAC or adducts) were dissolved in $10 \mathrm{~mL} \mathrm{1:1} \mathrm{mixture} \mathrm{of} \mathrm{upper} \mathrm{and} \mathrm{lower} \mathrm{layers} \mathrm{and}$ injected into the CPC systems. Elution was monitored using scan 200-600; 280 and $350 \mathrm{~nm}$ wavelengths, collecting fractions in $32 \mathrm{~mL}$ tubes. Fractions with similar composition were reunited according with on-line UV spectra and TLC.

\subsection{Thin Layer Chromatography and LC-MS analysis}

The formation of the adduct products, TLC analysis on silica gel pre-coated 60 F254 plates (Merck) was performed. Mobil phase was toluene: acetone: formic acid $3: 6: 1 \mathrm{v} / \mathrm{v} / \mathrm{v}$. For detection, plates were dried and derivatized by immersion in $20 \mathrm{~mL}$ of the reagent DMACA $(0.06 \mathrm{~g}$ plus $13 \mathrm{~mL} \mathrm{HCl}$ and $200 \mathrm{~mL}$ ethanol) [20]. Catechin and epicatechin were used as standards for comparison. Direct infusion ESI-MS experiments were performed using Nexera UHPLC System (Shimadzu, Japan) coupled to 3200 QTRAP Mass spectrometer (ABSCIEX, USA, MA). HPLC-DAD-ESI-MS/MS separations were done in a core-shell C18 column (Kinetex $150 \times 4.6 \mathrm{~mm}, 2.6 \mu \mathrm{m}$ ) protected by a UHPLC C18 pre-column (4.6 mm, $2.6 \mu \mathrm{m})$ (Phenomenex, USA, CA) using chromatographic conditions previously published for Peumus boldus proanthocyanidins [3].

\subsection{Helicobacter pylori culture conditions}

Helicobacter pylori (ATCC 43504) was used as the reference strain (Microbiology Laboratory, Faculty of Biological Sciences, and University of Concepcion). The strain was incubated in a microaerophilic environment $\left(10 \% \mathrm{CO}_{2}, 5 \% \mathrm{O}_{2}\right.$ and $\left.80 \% \mathrm{~N}_{2}\right)$ for 3 days on Columbia agar plates with $10 \%$ defibrinated horse blood and DENT.

\subsection{Screening disk diffusion test}

Susceptibility of Helicobacter pylori ATCC43504 strain to avocado PACs and flavan-3-ols adducts prepared with pyrogallol and resorcinol was assessed by disk diffusion using a suspension of $6 \times 10^{8} \mathrm{CFU} / \mathrm{mL}\left(\mathrm{McF}\right.$ arland $\left.\mathrm{N}^{\circ} 2\right)$ disseminated onto Müeller-Hinton agar plates containing 5\% of defibrinated horse blood. After bacterial suspensions were inoculated in agar surfaces compounds were added to $6 \mathrm{~mm}$ holes cut in the agar plates. The plates were incubated during $3-5$ days at $37^{\circ} \mathrm{C}$ under microaerophilic atmosphere $(15 \%$ $\mathrm{CO}_{2}, 5 \% \mathrm{O}_{2}$, and $80 \% \mathrm{~N}_{2}$ ). Amoxicillin $25 \mathrm{mg}$ (SDA, Santiago, Chile) was used as control. All experiments were performed in triplicate.

\subsection{Minimal Inhibitory Concentration}

The MIC for each compound was determined through micro dilution in broth, according to the recommendations made by the Clinical and Laboratory Standards Institute (CLSI, 2010) [21]. As a positive control of $H$. pylori strain inhibition, we used dilutions prepared form amoxicillin $2 \mu \mathrm{g} / \mathrm{mL}$. MICs values were defined as the lowest polyphenol concentration that completely inhibited visible growth of $H$. pylori.

\subsection{Cell culture and Cytotoxicity assay}

AGS cells were obtained from American Type Culture Collection
(Manasas, VA, USA). Cells were cultured as monolayers (ATCC) in plates of $55 \mathrm{~cm}^{2}\left(1-2 \times 10^{5}\right.$ cells $\left./ \mathrm{cm}^{2}\right)$, until $80 \%$ confluence was reached. Culture medium was RPMI $164090 \%$ containing $10 \%$ fetal bovine serum, $2 \mathrm{~mm}$ GlutaMAX, $100 \mathrm{U} / \mathrm{mL}$ penicillin, and $100 \mu \mathrm{g} / \mathrm{mL}$ streptomycin (humidified atmosphere, $5 \% \mathrm{CO}_{2}, 37^{\circ} \mathrm{C}$ ). The medium was changed twice a week. Cells were detached with $0.5 \mathrm{mg} / \mathrm{mL}$ trypsin containing $0.2 \mathrm{mg} / \mathrm{mL}$ EDTA in PBS and its viability was determined by trypan blue dye exclusion method [22]. PAC and adducts were tested up to $1000 \mu \mathrm{g} / \mathrm{mL}$ dissolved in RPMI medium. Plates were incubated for 3 hours and then $10 \mu \mathrm{l}$ of resazurin was added to each well. Absorbance at $570 \mathrm{~nm}$ and $600 \mathrm{~nm}$ was recorded after 2 hours [23].

\subsection{Anti-adhesion assays and IL-8 determination in H. pylori infected} AGS cells

For anti-adhesion experiments we used a previously published methodology with slight modifications [3, 24]. ATCC 43504 strain was labelled by incubation with $10 \mu \mathrm{L}$ of $0.1 \%$ FITC in DMSO for $1 \mathrm{~h}\left(25^{\circ} \mathrm{C}\right.$, in the dark). Excess of FITC was removed washing three times with RPMI containing $0.1 \%$ Tween 20 . PACs and adducts were prepared in PBS buffer and added to $24 \mathrm{~h}$ confluent AGS cells in 96 wells microplates. Immediately, $100 \mu \mathrm{L}$ of FITC- $H$. pylori was added to each well and incubated $3 \mathrm{~h}$. After incubation, media were removed and conserved for IL-8 analysis. Wells containing free FITC with different polyphenols concentrations were prepared to discard fluorescence quenching. Plates were washed three times with PBS buffer and the fluorescence of each well was immediately documented using the in vivo molecular imaging system UVP IBOX Scientia with excitation and emission filters 502-547 nm and 565-625 nm, respectively. For IL-8 analysis, an ELISA commercial Kit (Pharmingen) was used according with the fabricant instructions.

\subsection{Statistical analysis}

Data were analyzed using the GraphPad Prism 4 statistical software. Values represent the means of at least three independent experiments, each conducted in quadruplicate. Data were analyzed by analysis of variance with post hoc comparison using Tukey's test.

\section{RESULTS}

\subsection{PAC purification and synthesis of adducts}

In table 1 is summarized the yield of proanthocyanidins (PACs) extracted from avocado peels and the corresponding amount of semi-synthetic adducts prepared with pyrogallol and resorcinol. To improve the production of such compounds we work only with the polymeric PACs fraction (DPm $>10$ ). This fraction was obtained from the avocado peel extract using elution-extrusion centrifugal partition chromatography strategy (CPC1 method, ascending mode). With this preparative technology it was possible to separate the polymeric PAC fraction from the rest of the low molecular weight polyphenolic compounds present in avocado peel (Figure 1A). Polymeric material that was collected after 200 min (extrusion step) was used to prepare the flavan-3-ols adducts. For the synthesis of these compounds we perform the cleavage of PACs in acidic medium allowing nucleophilic attack with pyrogallol and resorcinol $[18,19]$.

Table 1: Yields of polyphenol extract from avocado peel, polymeric PACs fraction and semi-synthetic derivatives.

\begin{tabular}{|c|c|c|c|c|}
\hline Source & $\begin{array}{c}\text { Polyphenolic } \\
\text { extract }^{\mathrm{a}}\end{array}$ & $\begin{array}{c}\text { Polymeric } \\
\text { extract } \\
\text { (PACs) }^{\mathrm{b}}\end{array}$ & $\begin{array}{c}\text { Epicatechin- } \\
\text { resorcinol }^{\mathrm{c}}\end{array}$ & $\begin{array}{c}\text { Epicatechin- } \\
\text { pyrogallol }^{\mathrm{c}}\end{array}$ \\
\hline $\begin{array}{c}\text { Avocado } \\
\text { Fresh Peel }\end{array}$ & $27 \mathrm{~g}$ per $\mathrm{kg}$ & $350 \mathrm{mg} / \mathrm{g}$ & $180 \mathrm{mg} / \mathrm{g}$ & $216 \mathrm{mg} / \mathrm{g}$ \\
\hline
\end{tabular}

a Yield calculate on fresh weight basis.

b Yield calculate on dry weight of polyphenolic extract

${ }^{c}$ Yield calculate on dry weight of polymeric PACs fraction 

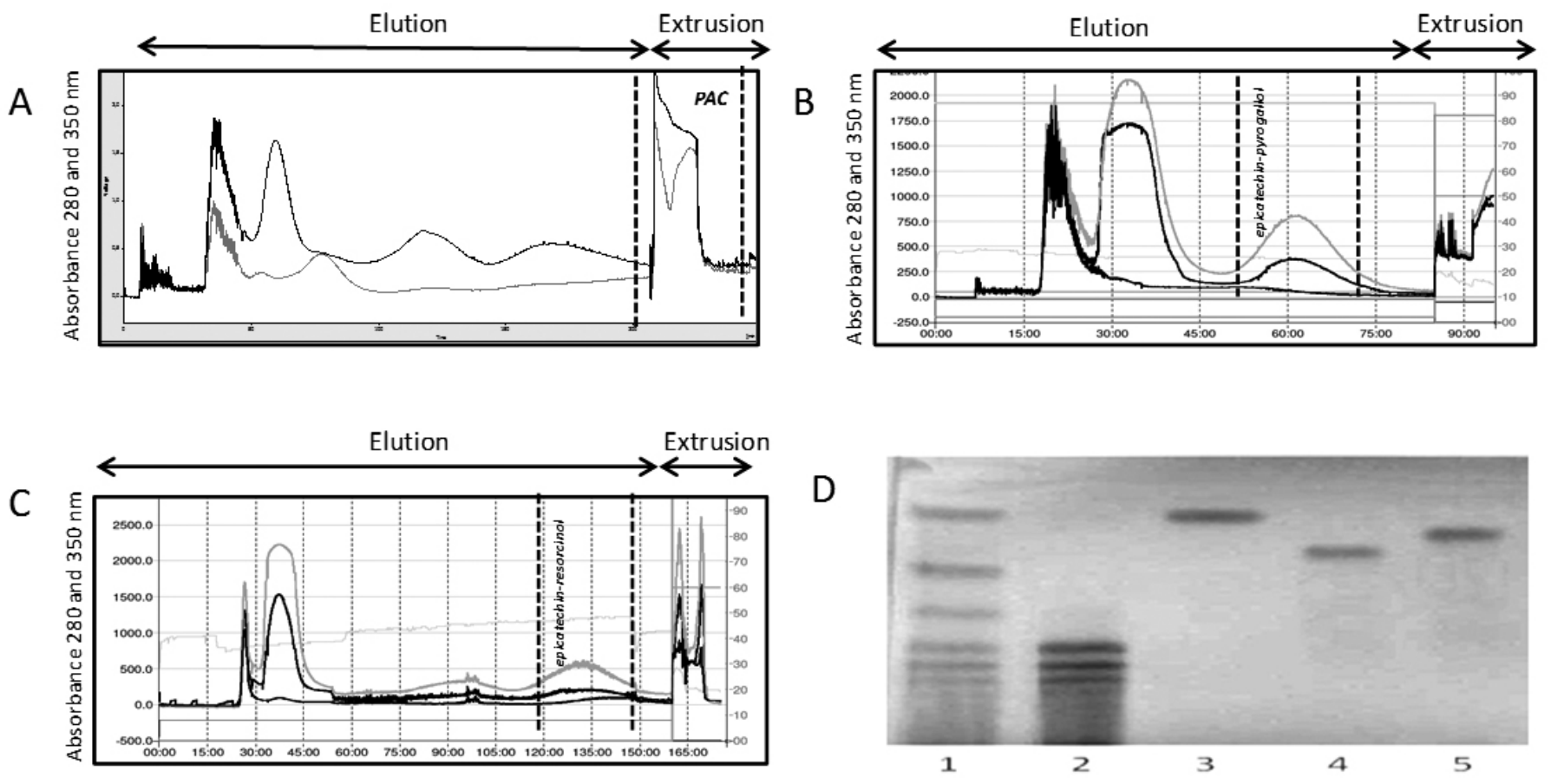

Figure 1: Purification of avocado peel PACs and their semi-synthetic adducts. (A), CPC chromatogram of avocado peel extract (ascending mode). (B), Chromatogram of pyrogallol-induced depolymerization mix of avocado peel PACs in ascending mode. (C), Chromatogram of resorcinol-induced depolymerization mix of avocado peel PACs in ascending mode. (D), TLC of avocado peel extract (Lane 1), avocado peel polymeric PACs obtained after CPC extrusion step (Lane 2), epicatechin (Lane 3), epicatechin-pyrogallol adduct (Lane 4) and epicatechin-resorcinol adduct (Lane 5).

Finally, phenolic adducts were purified by CPC, using CPC2 method, (ascending mode). The reaction mix was separated using the same biphasic solvent system used for PACs purification. Because CPC2 equipment have larger separation cells than CPC1 device, higher flow-rate $(15 \mathrm{~mL} / \mathrm{min})$ shorter separation times and high retentions of stationary phase $(85 \%)$ were possible. Figure 1 (A, B, C) shows CPC chromatograms for each sample. It was observed that a better yield was obtained when depolymerization was carried out with pyrogallol (Table 1). As is seen in Figures $1 \mathrm{~B}$ and $1 \mathrm{C}$ both adducts were successfully purified in one-step. In Figure 1D, a representative TLC of the $\mathrm{CPC}$-isolated products is showed. In the TLC lane 1 , crude avocado peel extract was spotted for comparison with high molecular weight PACs after been recovered in extrusion step of the CPC separation and applied in TLC lane 2. The formation of both adducts was confirmed in this TLC analysis. So, high molecular weight PACs of avocado peel (lane 2) have not coincident bands with those observed in lanes 4 and 5 . The purity of pyrogallol and resorcino adducts also can be checked when they are compared with epicatechin standard (lane 3). Additionally, direct infusion in ESI-MS of both adducts allowed to check the purification process. In Negative ion mode, epicatechin-pyrogallol exhibits a [M-H] ion at $m / z$ 413.5, whilst epicatechin-resorcinol exhibits a [M$\mathrm{H}]^{-}$ion at $m / z$ 398.9. These results agree with previous works [18, 19]. Finally, the formation of both derivatives was confirmed HPLC-DAD-ESI-MS/MS (Figures $2 \mathrm{~A}$ and $\mathrm{B}$ ). The peak at $\mathrm{t}_{\mathrm{R}} 15.07$ min showed the enhanced mass spectrum (EMS) that corresponds to epicatechin-pyrogallol derivative after purification (Figure 2A, upper spectrum). This peak was subsequently analyzed using Enhanced Product Ion (-EPI) obtaining high intensity fragments of the pseudomolecular ion (Figure 2A, lower spectrum). As expected from previous direct infusion ESI-MS experiments, this compound gave pseudomolecular ion at $\mathrm{m} / \mathrm{z} 413.5$ and characteristic MS2 fragments at $\mathrm{m} / \mathrm{z} 287.3$ (cleavage of pyrogallol moiety), 269.3 (water loss). Finally, heterocyclic ring fission gave fragments at $\mathrm{m} / \mathrm{z} 161.3$ and $\mathrm{m} / \mathrm{z} 125.2$, which are characteristic for those produced by this adduct in negative mode [18]. The peak at $t_{\mathrm{R}} 16.7 \mathrm{~min}$ showed the enhanced mass spectrum (EMS) that corresponds to epicatechinresorcinol derivative after purification (Figure $2 \mathrm{~B}$, upper spectrum). This peak was subsequently analyzed using Enhanced Product Ion (-EPI) obtaining high intensity fragments of the pseudomolecular ion (Figure 2B, lower spectrum). As expected from previous direct infusion ESI-MS experiments, this compound gave pseudomolecular ion at $\mathrm{m} / \mathrm{z} 397.4$ and characteristic MS2 fragments at $m / z$ 287.3 (cleavage of resorcinol moiety), 271.3 (water loss). Finally, heterocyclic ring fission gave fragments at $\mathrm{m} / \mathrm{z} 161.3$ and $\mathrm{m} / \mathrm{z} 125.2$.

\subsection{Cell viability assay}

Prior to test bacterial adhesion on AGS cells, an assay was performed to determine the concentrations of compounds that did not affect cell viability. Based on the graph obtained, it can be observed that cell survival remains around $90 \%$ up to $1000 \mu \mathrm{g} / \mathrm{mL}$ in most cases. Therefore, to maintain cell viability $>90 \%$ in all the experiments, the highest concentration assayed was $700 \mu \mathrm{g} / \mathrm{mL}$ (Figure 3A). 
-EMS: Exp 1, 15.074 min from Sample 4 (Catequina pyro) of 210417.wiff (Turbo Spray)
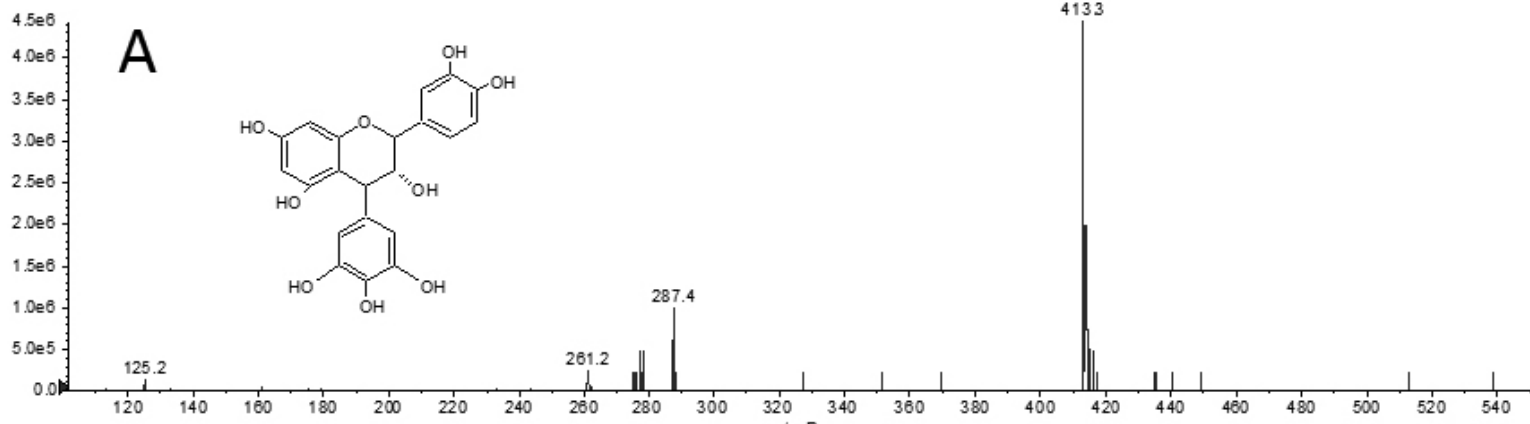

-EPT (413.16) Charge (+1) CE $(-32.7567)$ CES (-4) FT (109.478): Exp 2, $14.920 \mathrm{~min}$ fiom Sample 4 (Catequina pyro) of 210417.wiff (Tu

$\operatorname{Max} 1.06 \mathrm{cps}$

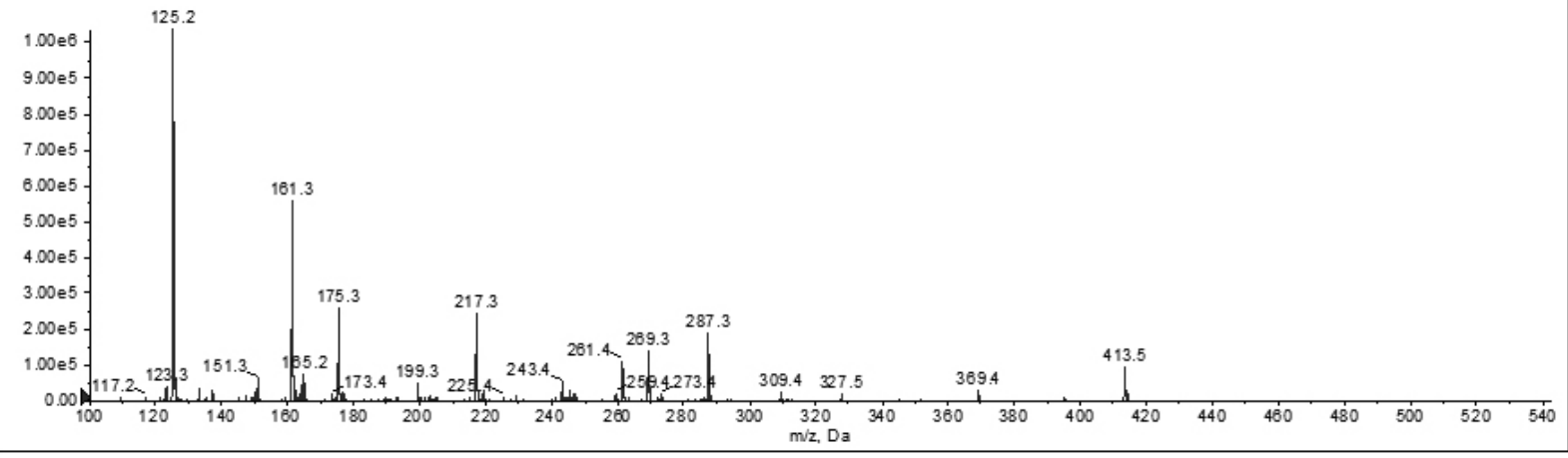

B

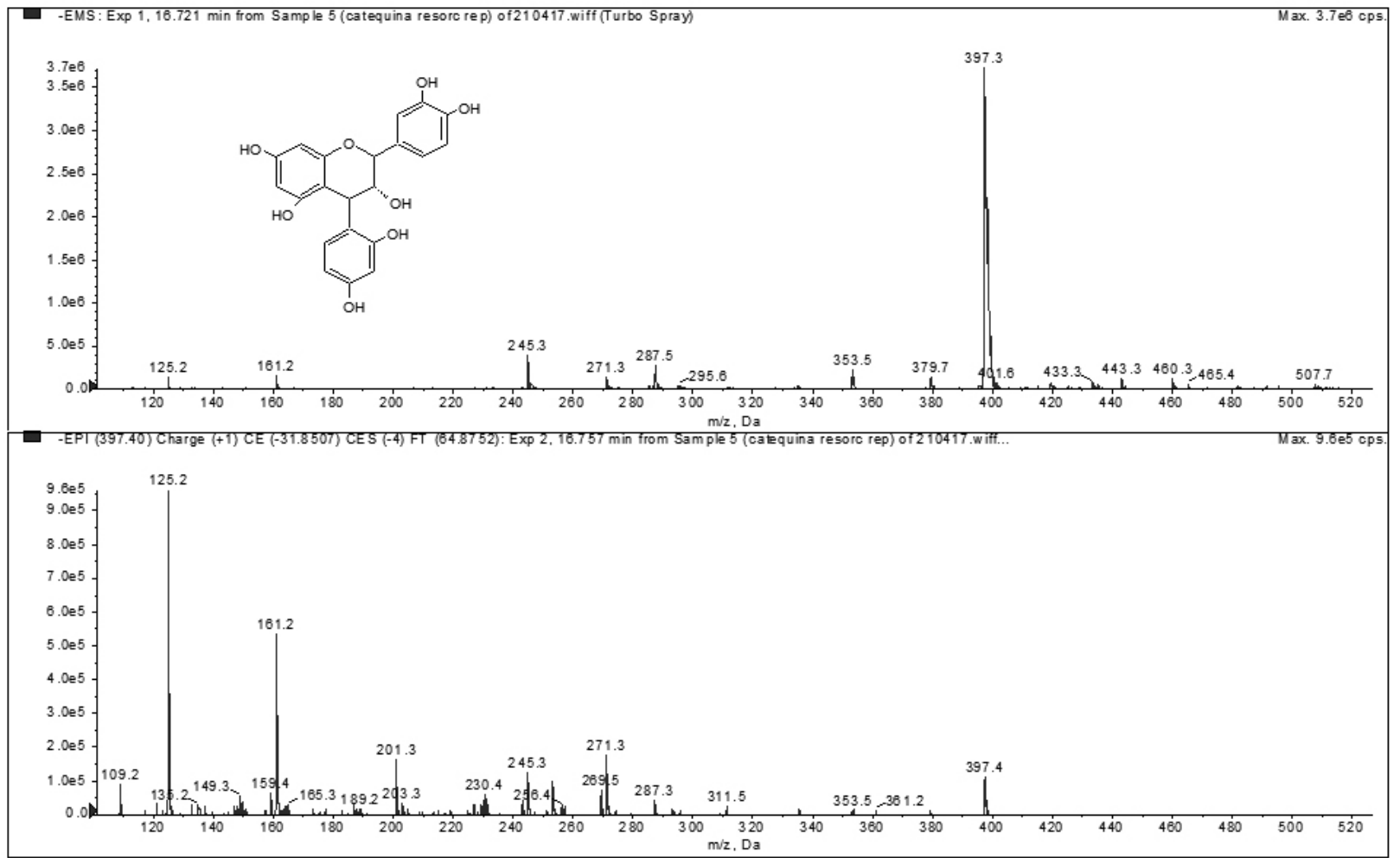

Figure 2. HPLC-DAD-ESI-MS/MS of epicatechin adducts of pyrogallol and resorcinol purified by CPC showing their identification in negative polarity. (A) The enhance mass spectrum for peak at $\mathrm{t}_{R}=15.07 \mathrm{~min}$ of epicatechin-pyrogallol that presented a pseudomolecular ion at $413.3 \mathrm{~m} / \mathrm{z}$. (B) The enhance mass spectrum for peak at $\mathrm{t}_{R}=16.72 \mathrm{~min}$ of epicatechin-resorcinol that presented a pseudomolecular ion at $397.3 \mathrm{~m} / \mathrm{z}$. ESI-MS/MS results are depicted in the inferior panels of Figures $2 \mathrm{~A}$ and $2 \mathrm{~B}$ as enhanced product ions spectrum (EPI). 
A

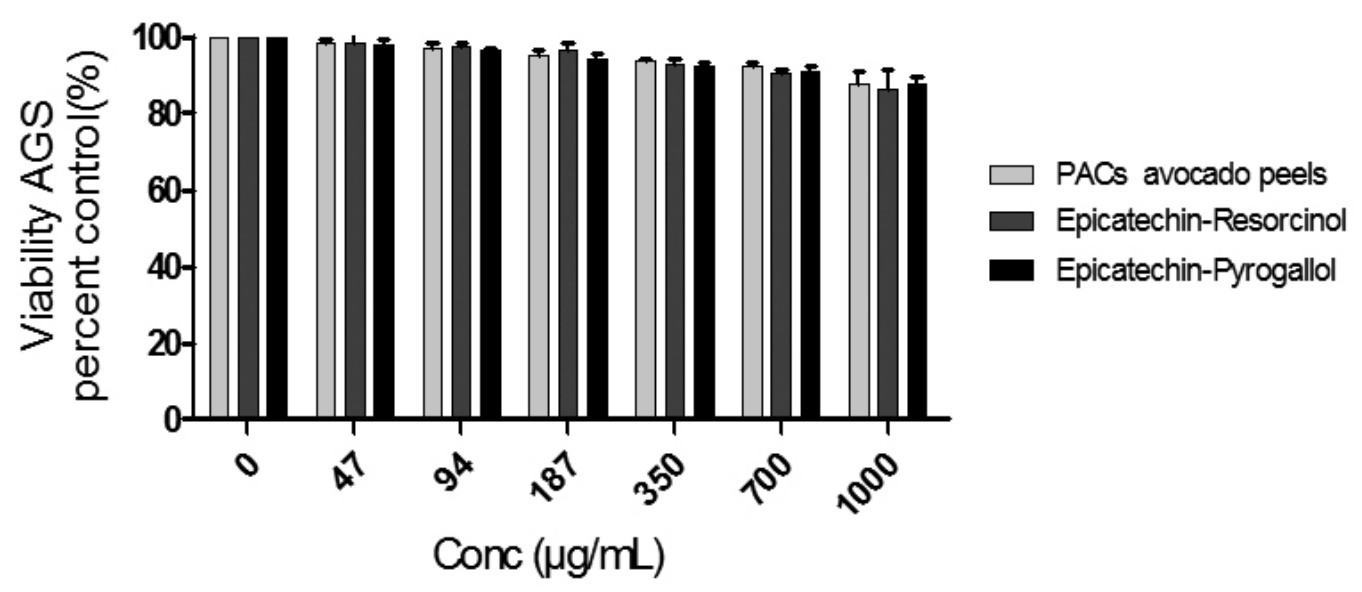

B

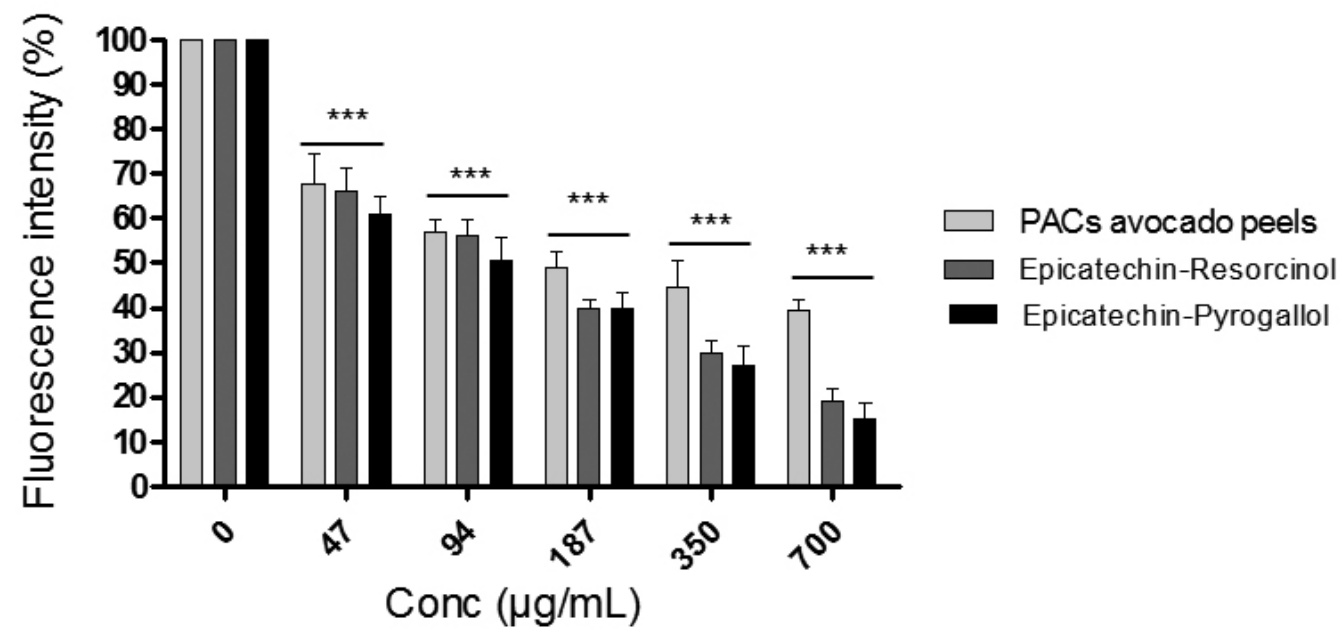

C

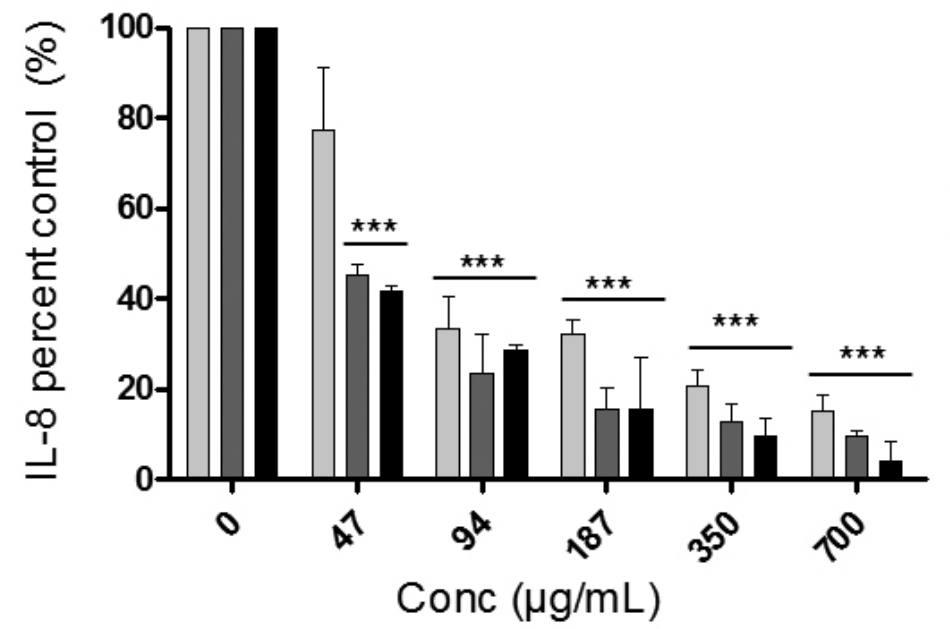

Figure 3: (A) Citotoxicity of avocado PACs and adducts against AGS cell line at the concentration ranging from 47 to 1000 $\mu \mathrm{g} / \mathrm{mL}$. (B) Inhibitory effect of avocado PACs and adducts on bacterial adherence to AGS cells after pre-incubation followed by infection with $H$. pylori ATCC 43504. (C) Effect of avocado PACs and adducts on IL-8 release by AGS cells infected with $H$. pylori ATCC 43504. Data are representative of three independent experiments performed in triplicate; $* * * p<0.05$ (versus control 0 ). 
3.3. Effect of avocado PACs and adducts on $\mathrm{H}$. pylori viability, adherence to $A G S$ cells and $I L-8$ secretion

Anti-H. pylori effect of avocado peel PACs and its adducts is summarized In Table 2. Clearly, antimicrobial effect of avocado PACs and the phenolic adducts is low. Compared with amoxicillin $(62 \mathrm{~mm})$, the diameter of zones of Inhibition were very small $(11-12 \mathrm{~mm})$. In line with these results, minimum inhibitory concentrations $\left(\mathrm{MIC}_{90}\right)$ were in all cases higher than $900 \mathrm{mg} / \mathrm{mL}$, whereas for amoxicillin it was $0.04 \mathrm{mg} / \mathrm{mL}$. Using the range $47-700 \mathrm{mg} / \mathrm{mL}$ of avocado PACs and pyrogallol/resorcinol adducts, the effect on bacterial adhesion to AGS cells was determined by measuring the fluorescence intensity of FITC-labeled $H$. pylori. Figure 3B shows the percentage of fluorescence intensity after incubation with each compound at different concentrations. Data were normalized using AGS cells infected with FITC-labeled $H$. pylori (nontreated AGS) as $100 \%$ fluorescence intensity. The presence of avocado PACs and pyrogallol/resorcinol adducts did not quenched FITC fluorescence in cellfree media in the concentration range used (data not shown). The graphs made with ATCC 43504 strain clearly show that all compounds succeed in inhibiting the adhesion of labeled $H$. pylori to AGS cells. This inhibition was dependent of the concentration because at lower concentration $(47 \mu \mathrm{g} / \mathrm{mL})$ fluorescence intensity range between $60 \%$ and $65 \%$, indicating higher $H$. pylori adhesion to AGS cells. In contrast, the highest concentration $(700 \mu \mathrm{g} / \mathrm{mL})$ reduced $H$. pylori adhesion to $39.3 \%$ for PAC. However, bacterial adhesions of $19 \%$ and $15 \%$ were observed for resorcinol and pyrogallol derivatives, respectively. It is also observed that there is concentration dependence, since as the concentration of compounds increases from 47 to $700 \mu \mathrm{g} / \mathrm{mL}$, the adhesion of $H$. pylori decreases dramatically.

Table 2: Anti-Helicobacter pylori activities of avocado peel PACs and adducts obtained by nucleophilic attack with resorcinol and pyrogallol.

\begin{tabular}{|c|c|c|}
\hline Sample & $\begin{array}{c}\text { H. pylori ATCC } \\
43504 \\
\text { Halo }(\mathrm{mm})\end{array}$ & $\begin{array}{c}\text { H. pylori ATCC } \\
\text { 43504 } \mathrm{MIC}_{90}(\mu \mathrm{g} / \mathrm{mL})\end{array}$ \\
\hline PACs avocado peels & $\mathrm{R}$ & $>1500$ \\
\hline Epicatechin-resorcinol & 12 & 965.4 \\
\hline Epicatechin-pyrogallol & 11 & 970.1 \\
\hline Epicatechin & $\mathrm{R}$ & $>1500$ \\
\hline Procyanidin C2 $^{2}$ & $\mathrm{R}$ & $>1500$ \\
\hline Amoxicilin $^{\mathrm{a}}$ & 62 & 0.04 \\
\hline
\end{tabular}

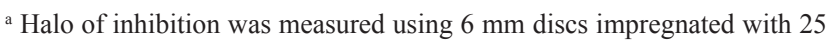
$\mu \mathrm{g}$ of amoxicillin.

On the other hand, we analyzed the production of IL-8, which is a proinflammatory cytokine that reflects early steps of the $H$. pylori inflammatory damage to gastric mucosa. Interlekin-8 was determined using ELISA kit on the supernatants taken from the bacterial adhesion assay. Figure $3 \mathrm{C}$ shows that from $94 \mu \mathrm{g} / \mathrm{mL}$ concentration of avocado peel PACs there are a statistically significant reduction of IL-8 production. As example, with $700 \mu \mathrm{g} / \mathrm{mL}$ of avocado PACs, such inhibition reached an $85 \%$ with respect to control (noninfected AGS cells). By another side, in the assayed concentration range 47$700 \mu \mathrm{g} / \mathrm{mL}$ of both semi-synthetic compounds, we observe a concentrationdependent effect and highly significant differences compared with no-infected AGS cells (Figure 4C). For instance, the inhibition of IL-8 secretion in $H$. pylori-infected AGS treated with $700 \mu \mathrm{g} / \mathrm{mL}$ of epicatechin-resorcinol and epicatechin-pyrogallol adducts was almost complete, reaching $90.6 \%$ and 95.9 $\%$, respectively.

\section{DISCUSSION}

In this work, as source of polyphenols we used avocado peel. In previous publication we found that this resource has high amounts of polyphenols like epicatechin-based PACs plus another low molecular weight phenolic compounds [26]. Using aqueous extraction of 1 kilogram of fresh peel it was possible to obtain $27 \mathrm{~g}$ of dry polyphenolic extract ( $2.7 \%$ yield). To improve the yield of the depolymerization reaction with two selected nucleophiles we chose to concentrate the polymeric fraction of these PACs through CPC1. In general, both PACs and semi-synthetic compounds showed inhibition against $H$. pylori adhesion, being epicatechin-pyrogallol derivative the most effective. The obtained results suggest that avocado peel PACs and its adducts would be able to affect $H$. pylori adhesion mechanisms, which could hinder its permanence in the gastric epithelium. This inhibition could be partially explained by a direct antimicrobial mechanism. Nevertheless, in the range of concentration assayed, the $H$. pylori viability was slightly affected. Alternatively, adhesion could be indirectly affected by inhibition of enzymes such as urease and carbonic anhydrase activities. These enzymes play a key role in the $H$. pylori resistance to acid environment found in the stomach $[27,28]$. The sum of these mechanisms could eventually prevent $H$. pylori from adhering to the cells. Rohdewald \& Beil demonstrated that an extract rich in pine bark PACs (Pycnogenol) inhibited the adherence of $H$. pylori in a concentration-dependent manner to AGS cells [29]. Based on the above mentioned in the text, our group attempted to evaluate an apple peel extract rich in polyphenols (APPE), against H. pylori adhesion and vacuolization in HeLa cells [30]. In this previous study we found that APPE exerts a dual anti-H. pylori effect, inhibiting the bacterial adhesion process and their urease activity. The anti-adherence effect of APPE was observed with $\mathrm{IC}_{50}=5.3 \mathrm{mg} / \mathrm{mL}$. However, it must be mentioned that APPE extracts has only a $22 \%$ of PACs and $58 \%$ of flavonoids whereas the avocado PACs used in the present study were concentrated by CPC and contain exclusively polymeric PACs ( $>77 \%$ ) with high molecular weight (DPm 6.10) [26]. H. pylori adhesion to host cells induces the expression of virulence factors that cause tissue damage and subsequently release of cytokines. Therefore, in addition to the adhesion assay, a complementary experiment was performed with the aim to measure the production of IL-8. In this study, a decrease in IL-8 production was observed in the analyzed treatments with respect to the control. Interestingly, epicatechin-pyrogallol induce a potent anti-inflammatory effect, even greater than that observed for avocado peel PACs. Due to its lower molecular size and polarity compared to PACs, it is more likely that these compounds could penetrate inside AGS cells. So, once inside cells they could promote antioxidant and anti-inflammatory defense mechanisms.

\section{CONCLUSIONS}

All compounds (avocado PACs and its adducts were able to achieve a significant decrease in bacterial attachment to AGS cells. Importantly, epicatechin-adducts lowers the secretion of early pro-inflammatory signals (IL-8) in such infected-AGS cells. Finally, this decrease in adherence and the potential anti-inflammatory effect was dependent of the compounds concentration. Nowadays, the search of non-antibiotic substances against H. pylori is a very important task. In the present work, we demonstrate that avocado peel PACs and their semi-synthetic derivatives could be of interest for the complementary manage or prevention of this infection. Moreover, the possibility for using cheap sources of procyanidins (agricultural wastes) is very interesting because it will allow us to synthesize new molecules with high cytoprotective capacity associated to antimicrobial mechanisms.

\section{ACKNOWLEDGMENTS}

This work was supported by the Comision Nacional Científica y Tecnológica, Chile, Programa FONDECYT [Grant number 1150948] and Programa FONDEQUIP [Grant number 150025].

\section{REFERENCES}

[1] Fine, AM. Oligomeric proanthocyanidin complexes: history, structure, and phytopharmaceutical applications. Altern. Med. Rev 2000, 5: 144-51.

[2] Pastene, E.; Troncoso, M.; Figueroa, G.; Alarcón, J.; Speisky, H. Association between Polymerization Degree of Apple Peel Polyphenols and Inhibition of Helicobacter pylori Urease. J. Agric. Food Chem, 2009, 57: 416-424.

[3] Pastene, E.; Parada, V.; Avello, M.; Ruiz, A.; García, A. Catechinbased Procyanidins from Peumus boldus Mol. Aqueous Extract Inhibit Helicobacter pylori Urease and Adherence to Adenocarcinoma Gastric Cells. Phytother Res, 2014, 28: 1637-1645.

[4] Torres, JL.; Lozano, C.; Juliá, L.; Sánchez-Baeza, J.; Anglada, JM.; Centelles, JJ.; Cascante, M. Cysteinyl-flavan-3-ol Conjugates from Grape Procyanidins. Antioxidant and Antiproliferative Properties. Bioorg. Med. Chem, 2002, 10: 2497-2509.

[5] Mitjans, M.; Martínez, V.; del Campo, J.; Abajo, C.; Lozano, C.; Torres, JT.; Vinardell, P. Novel epicatechin derivatives with antioxidant activity modulate interleukin-1 $\beta$ release in lipopolysaccharide-stimulated human blood. Bioog. \& Med. Chem. Lett, 2004, 14: 5031-5034.

[6] Ugartondo, V.; Mitjans, M.; Lozano, C.; Torres, JL.; Vinardell, MP. 
Comparative Study of the Cytotoxicity Induced by Antioxidant Epicatechin Conjugates Obtained from Grape. J. Agric. Food Chem, 2006, 54: 69456950 .

[7] Carreras, A.; Mesa, JA.; Cascante, M.; Torres, JL.; Juliá, L. High electron transfer capacity of thio-derivatives of tea catechins measured using a water soluble stable free radical and their effects on colon cancer cells. New J. Chem, 2013, 37: 2043-2050.

[8] Wroblewski, L.E.; Peek, R.M.; Wilson K.T. Helicobacter pylori and gastric cancer: Factors that modulate disease risk. Clin Microbiol Rev 2010, 23, 713-739.

[9] Go, M. Natural history and epidemiology of Helicobacter pylori infection. Aliment Pharmacol Ther, 2002, 16, 3-15.

[10] Malfertheiner, P.; Megraud, F.; O’Morain, CA.; Gisbert, JP.; Kuipers, EJ.; Axon, AT.; Bazzoli, F.; Gasbarrini, A.; Atherton, J.; Graham, DY.; Hunt, R.; Moayyedi, P.; Rokkas, T.; Rugge, M.; Selgrad, M.; Suerbaum, S.; Sugano, K.; El-Omar, EM. Management of Helicobacter pylori infection the Maastricht V/ Florence Consensus Report. Gut, 2017, 66: 646-664.

[11]Ferreccio, C.; Rollán, A.; Harris, PR.; Serrano, C.; Gederlini, A.; Margozzini, P.; Gonzalez, C.; Aguilera, X.; Venegas, A.; Jara, A. Gastric Cancer is related to Early Helicobacter pylori Infection in a HighPrevalence Country. Cancer Epidemiol Biomarkers Prev, 2007, 16: 662 667.

[12]Peek, R.M; Crabtree, J.E. 2006. Helicobacter infection and gastric neoplasia. J Patho, 2006, 208, 233-248.

[13] Sachs, G.; Scott, D. Helicobacter pylori: eradication or preservation. F1000 Med Rep 2012, 4, 7 .

[14]Parkin, D.M.; Bray, F.; Ferlay, J.; Pisani, P. Global cancer statistics, 2002. CA: CA Cancer J Clin, 2005, 55: 74-108.

[15] Teixeira Mendes, S.; Attygalle, D.; Wotherspoon, C. Helicobacter pylor infection in gastric extranodal marginal zone lymphoma of mucosaassociated lymphoid tissue (MALT) lymphoma: a re-evaluation. Gut, 2014, 63, 1526-1527.

[16] Dacoll, C.; Balter, H.; Varela, L.; Buenavida, G.; González, N.; Silveira, A.; Cohen, H. Evolución de la respuesta al tratamiento de primera línea de la infección por Helicobacter pylori en Uruguay. Acta Gastroenterol Latinoam. 2014, 44: 88-93.

[17] Martínez, M.; Henao, R.; Lizarazo, R. Resistencia antibiótica de Helicobacter pylori en América Latina y el Caribe. Rev Col Gastroenterol, 2014, 29: 218-227.

[18]Köhler, N.; Wray, V.; Winterhalter, P. Preparative isolation of procyanidins from grape seed extracts by high-speed counter-current chromatography. $J$ Chromatogr A, 2008, 1177: 114-125.

[19]Bordiga, M.; Coïsson, JD.; Locatelli, M.; Arlorio, M.; Travaglia, F. Pyrogallol: An Alternative Trapping Agent in Proanthocyanidins Analysis. Food Anal. Methods, 2013, 6: 148-156.

[20] Glavnik, V.; Simonovska, B.; Vovk, I. Densitometric determination of $(+)$-catechin and (-)-epicatechin by 4-dimethylaminocinnamaldehyde reagent. J. Chromatogr A, 2009; 1216: 4485-4491.

[21] National Committee for Clinical Laboratory Standards. 2000. Performance standards for antimicrobial susceptibility testing. Approved standard M7A5. Informational supplement M100-S10. NCCLS, Wayne, Pa.

[22] Tolnai, S. A method for viable cell count. Methods Cell Sci, 1975, 1: 37 38 .

[23] Sarker, SD.; Nahar, L.; Kumarasamy, Y. Microtitre plate-based antibacterial assay incorporating resazurin as an indicator of cell growth, and its application in the in vitro antibacterial screening of phytochemicals. Methods, 2007, 42: 321-324

[24]Beil, W.; Kilian, P. EPs 7630 an extract from Pelargonium sidoides roots inhibits adherence of Helicobacter pylori to gastric cells. Phytomedicine, 2007, 14: 5-8

[25] Scott, DR.; Weeks, D.; Hong, C.; Postius, S.; Melchers, K.; Sachs, G. The role of internal urease in acid resistance of Helicobacter pylori. Gastroenterology, 1998, 114: 58-70.

[26]Chávez, F.; Aranda, M.; García, A.; Pastene, E. Los polifenoles antioxidantes extraídos del epicarpio de Palta (Persea americana var. Hass) inhiben la ureasa de Helicobacter pylori. BLACPMA 2011; 10: 263 280.

[27] Salama, N.; Hartung, M.; Müller, A. Life in the human stomach: persistence strategies of the bacterial pathogen Helicobacter pylori. Nat Rev Microb, 2013, 11: 385-399.

[28] Marcus, E.; Moshfegh, AP:, Sachs, G.; Scott, DR. The periplasmic a-carbonic anhydrase activity of Helicobacter pylori is essential for acid acclimation. J Bacteriol, 2005, 187: 729-738.
[29] Rohdenwald, P.; Beil, W. In vitro inhibition of Helicobacter pylori growth and adherence to gastric mucosal cells by pycnogenol. Phytother Res, 2008, 22: 685-688.

[30]Pastene, E.; Speisky, H.; García, A.; Moreno, J.; Troncoso, M.; Figueroa, G. In Vitro and In Vivo Effects of Apple Peel Polyphenols against Helicobacter pylori. J. Agric. Food Chem, 2010, 58: 7172-7179. 